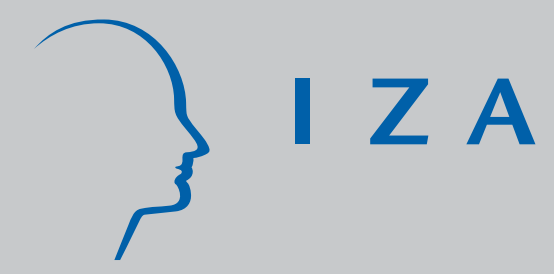

IZA DP No. 1447

Venture Capital Investment and Labor Market Performance:

New Empirical Evidence for OECD Countries

Ansgar Belke

Andreas Schaal

December 2004 


\title{
Venture Capital Investment and Labor Market Performance: New Empirical Evidence for OECD Countries
}

\author{
Ansgar Belke \\ University of Hohenheim \\ and IZA Bonn \\ Andreas Schaal \\ University of Hohenheim
}

\section{Discussion Paper No. 1447 \\ December 2004}

\author{
IZA \\ P.O. Box 7240 \\ 53072 Bonn \\ Germany \\ Phone: +49-228-3894-0 \\ Fax: +49-228-3894-180 \\ Email: iza@iza.org
}

\begin{abstract}
Any opinions expressed here are those of the author(s) and not those of the institute. Research disseminated by IZA may include views on policy, but the institute itself takes no institutional policy positions.

The Institute for the Study of Labor (IZA) in Bonn is a local and virtual international research center and a place of communication between science, politics and business. IZA is an independent nonprofit company supported by Deutsche Post World Net. The center is associated with the University of Bonn and offers a stimulating research environment through its research networks, research support, and visitors and doctoral programs. IZA engages in (i) original and internationally competitive research in all fields of labor economics, (ii) development of policy concepts, and (iii) dissemination of research results and concepts to the interested public.
\end{abstract}

IZA Discussion Papers often represent preliminary work and are circulated to encourage discussion. Citation of such a paper should account for its provisional character. A revised version may be available directly from the author. 


\begin{abstract}

\section{Venture Capital Investment and Labor Market Performance: New Empirical Evidence for OECD Countries*}

Anglo-Saxon countries have been successful in the 1990s concerning labor market performance compared to the former role models Germany and Japan. This reversal in relative economic performance might be related to idiosyncracies in financial markets with bank-based financial markets as in Germany and Japan being possibly inferior to stockmarket based financial markets in turbulent times and when approaching the economic frontier. A cleavage is related to venture capital markets which are flourishing on AngloSaxon but not on German type financial markets. Venture capital is crucial for financing structural change, new firms and innovations and therefore possibly also nowadays for employment growth.
\end{abstract}

JEL Classification: E22, E24, E44, G24, G32

Keywords: labor markets, venture capital, unemployment, new economy, panel data analysis

-- In memory of Rainer Fehn who died much too early! --

Corresponding author:

Ansgar Belke

Department of Economics

University of Hohenheim

70593 Stuttgart

Germany

Email: belke@uni-hohenheim.de

\footnotetext{
* This contribution is a modified version of Belke, Fehn and Foster (2003).
} 


\section{Introduction}

In spite of the recent cyclical downturn, there is a growing sense that the US has been steaming ahead again in terms of economic development compared to most OECD countries but especially compared to Germany and Japan, which not long ago, namely in the 1980s, were considered to be successful economic role models. The catch-up process of these two countries vis-à-vis the US does not only seem to be have stopped, but the gap appears to have begun to widen again. This is largely the result of a poor economic performance in the 1990s, especially in Japan, but also in reunified Germany with considerably lower growth rates of per capita GDP and of total factor productivity and a far less impressive labor market performance featuring lower and at times even negative employment growth and rising instead of falling NAIRUs.

The prime challenge to advanced economies is presented by the radical and rapid process of structural change, that is, the ongoing move from largely standardized products of the industrial sector to the service sector, but also to the fledgling areas of the new economy, such as biotechnology, information and internet technology, computers or the media. A second important challenge is due to the greater volatility and microeconomic turbulence of the economic environment that favors countries with a more flexible set of institutions in order to be able to respond quickly to shocks and to new economic opportunities. Countries with a rigid set of institutions that tends to stifle innovative entrepreneurship are therefore likely to fall behind in terms of economic development as reflected in growth of per capita GDP and of employment. ${ }^{1}$

A third and by now well-known challenge for Japan is solving the ongoing banking crisis. Interestingly, indicators are mounting nowadays that Germany may also stumble into a major banking crisis in 2003 with record rates of bankruptcies of firms and of banks having to write off large amounts of bad loans. Back in the 1980 s, both countries were heralded for their bank-based financial markets which had the same legal roots in the German law tradition ${ }^{2}$ and which supposedly gave them an institutional advantage due to stronger protection of creditor rights, more patient financial markets, potentially larger investment volumes and closer relationships between banks and large industrial companies for example. All these factors allegedly enable experienced managers to pursue a longer time horizon in their more discretionary and more large-scale investment policy supposedly to the long-term benefit not only of the firm's share- and stakeholders but also for the country concerned. Experienced managers can realize greater investment volumes and are better at adopting already existing technologies in large quantities. These two factors are the more important for the economic progress of a country, the

See Heckman (2002).

See La Porta et al. (1998). 
further away it is from the world frontier of economic development and were therefore potentially beneficial for Germany and Japan in the post-war period.

In contrast, when approaching the frontier it becomes more important for a country to innovate itself and thus to select the right managers and firms for undertaking promising innovations and new ventures as well as to have a smooth matching process between firms and financiers. Anglo-Saxon type stock-marketbased financial markets with fully developed venture capital markets tend to be superior in these types of selection and matching activities, inter alia because they give less shelter to entrenched managers who might not be innovative anymore, thus being more open to the entry of outsider entrepreneurs with new ideas. More turbulent times with rapid and radical structural change, along with a closer position to the frontier of economic development both appear to favor the AngloSaxon type institutional setting on financial markets with highly developed venture capital markets. ${ }^{3}$

The poor performance of Germany, particularly in terms of rising unemployment is usually blamed on its rigid labor market and its generous welfare state. ${ }^{4}$ However, it might in addition be the case for both, Germany and Japan, that the insider-oriented bank-based institutional setting of their financial markets is no longer an asset but rather a burden for realizing further economic progress and for improving labor market performance. The comparative institutional advantage concerning financial markets might have shifted over the last decade not only to the US but to Anglo-Saxon countries in general, which feature stock-market based financial markets with a stronger protection of shareholder rights and more developed venture capital markets. ${ }^{5}$ It is noteworthy in this respect that not only the US but also other Anglo-Saxon countries even within Europe, such as the UK and Ireland, have fared particularly well in the 1990s and into the new millennium in terms of growth of per capita GDP and of employment. They have both recently surpassed Germany in terms of their per capita GDP and have had a much better labor market performance.

Anglo-Saxon financial markets are characterized by highly developed stock markets and markets for initial public offerings, which are in turn essential for flourishing venture capital markets. Venture capital has in recent years played a key role especially in Anglo-Saxon countries in financing structural change, innovations and new firms. These factors are again essential for understanding employment performances over the last decade. Venture capital is a hybrid system between arm's length and relationship-based financing with venture capitalists not only mitigating financing constraints but potentially adding value via their sectorspecific business knowledge. Due to their experience and expertise, they can

See Acemoglu, Aghion and Zilibotti (2002), Hellmann and Puri (2000) and Kortum and Lerner (1998).

See, e.g., Siebert (1997) and Berthold and Fehn (2002).

See La Porta et al. (1998), Hubbard (1998) and Botazzi and Da Rin (2002). 
increase the survival rate of young firms in the particularly treacherous seed- and start-up phase of a new firm's economic lifecycle. Hence, venture capitalists are not just financiers but they perform important additional activities which unspecialized commercial banks are unable to perform like monitoring and giving helpful business advice to fledgling firms. ${ }^{6}$

In sum, highly developed venture capital markets might be a key element in the Anglo-Saxon institutional setting on financial markets, which contributed to producing a better labor market performance in comparison to countries which rely largely on bank financing and on internal financing in large established firms. If venture capital financing turns out to be empirically important for improving labor market performance, public policy must therefore step up efforts to reform financial market institutions so that a viable venture capital market develops.

The rest of the paper is organized as follows. Section 2 briefly presents a highly stylized macroeconomic model that depicts the negative employment effects of matching frictions on both, the labor and the financial market. This is done under the heuristic assumption that a fully developed venture capital market reduces matching frictions on the financial market. Section 3 is the core of the paper as it presents new panel data empirical evidence for the OECD countries concerning the relationship between venture capital investment and employment performance at the macro level. Section 4 offers policy conclusions.

\section{Matching Problems and Labor Market Tightness}

The lack of a well-functioning venture capital market represents a type of financial market imperfection. There exist a number of ways to model the spill-over effect of incomplete financial markets on labor market performance. This approach consists of combining matching problems on labor and financial markets in a macromodel assuming that a well-functioning venture capital market is conducive to reducing matching problems between firms and financiers, thus increasing labor market tightness and raising the quasi-equilibrium rate of employment. The essential building blocks of such a model are presented in the following. ${ }^{7}$ There are three types of actors in the model: Entrepreneurs with innovative ideas, financiers with capital, and workers. One individual of each group is necessary for setting up a firm. There are symmetric matching problems on the labor and the financial market. Firms and banks have difficulty in finding each other just as workers and firms do. In order to produce, though, entrepreneurs need both a worker and a financier so that both matching problems need to be resolved before any production can start. Starting with the labor market, entrepreneurs need to expend search costs $\gamma$ per period to encounter and hire a worker. A simple constant returns to scale

See Botazzi and Da Rin (2001) and Fehn (2002).

The following chapter is entirely based on the pioneering work of Wasmer and Weil (2000) and merely serves to lay a theoretical foundation for our own empirical analysis. 
matching function $h(U, V)$ is assumed with two inputs, the number of unemployed $U$ and of vacancies $V$, which are offered by all firms in the economy producing a flow of job matches: ${ }^{8}$

$$
\frac{h(U, V)}{V}=h\left(\theta^{-1}, 1\right) \equiv q(\theta) .
$$

A tighter labor market, that is, a higher value of $\theta \equiv V / U$, lowers the probability $q$ that a firm finds a suitable worker: $q^{\prime}(\theta)<0$.

Hence, in order to find a worker, a firm needs to obtain finance and to look for a financier or bank. It is assumed that there are symmetric matching problems also on the financial market. There are $F$ firms and $B$ banks and each of these $F$ firms has to spend $c$ search costs per period to look for a bank. The flow of financial contracts is given by the matching function $m(B, F)$. The difficulty of firms to find a suitable bank is represented by the ratio $\phi=F / B$. The inverse $\phi^{-1}$ is therefore a measure for the liquidity of the financial market. The probability that a firm encounters a suitable bank is defined as follows:

$$
\frac{m(B, F)}{F}=m\left(\phi^{-1}, 1\right) \equiv p(\phi),
$$

with the probability that a bank finds a firm being:

$$
\frac{m(B, F)}{B}=m(1, \phi) \equiv \phi p(\phi) .
$$

The first probability depends negatively and the second one positively on financial market tightness $\phi$.

The life of a firm can be separated into 4 consecutive periods of stochastic length:

- Fundraising: Potential entrepreneurs with ideas look in period 0 for banks to set up a firm expending a non-pecuniary flow search cost c. Conversely, banks search for suitable firms paying a flow search cost $k$. The probability of a match and thus that a firm moves on to the recruitment phase is given by $p(\phi)$.

- Recruitment: Firms look in period 1 for workers expending a flow search cost $\gamma$ that is financed by the bank met in the fundraising phase. The probability that a firm finds a suitable worker is given by $q(\theta)$.

- Production: Firms produce in period 2 with the aid of the worker hired in the recruitment phase that yields a flow revenue $y$. These cash flows are used to pay workers a given wage $\omega$ and banks the ex ante agreed upon price for capital $\rho$ per period in the production phase.

8 The matching function $\mathrm{h}$ is assumed to have the properties of a standard production function: $h_{U}>0, h_{V}>0, h_{U U}<0, h_{V V}<0$. 
- Destruction: Firms stop their productive activities with an exogenously given probability s and transit into period 3 in which they are dissolved.

The financial contract between the firm and the bank has two components: the bank provides the firm during the recruitment phase 1 with $\gamma$ money units per time period and the firm pays to the bank $\rho$ monetary units per time period during the production phase 2 . Total payments in both directions are therefore stochastic and the financial contract resembles a profit sharing or venture capital contract because the size of the payments from the firm to the bank during the production phase depends on profits and is not fixed. It is assumed that the firm and the bank divide the production surplus according to a Nash bargaining solution and that there is free entry of firms and banks into the goods and into the financial market respectively. Hence, there are no unused profit opportunities and expected search costs for banks and firms must equal expected profits in case of a successfully concluded contract.

This implies that the value of a matched bank is lower and that one of a matched firm is higher in a less liquid financial market with a higher $\phi$, that is, a high equilibrium number of firms relative to banks. Banks have to search less and firms more under such circumstances with many firms relative to banks. The equilibrium tightness of the financial market rises with greater search costs for firms $k$, whereas it depends negatively on search costs $c$ for banks. A higher relative bargaining power of banks relative to firms exerts a negative impact on the equilibrium tightness of the financial market, whereas labor market tightness $\theta$, that is, the equilibrium vacancy rate relative to the unemployment rate, does not affect the equilibrium on the financial market.

The graphic solution of the model in a diagram with labor and financial market tightness on the horizontal and vertical axis respectively is straightforward and highly intuitive. ${ }^{9}$ Let BB and FF be the entry or zero profit condition for banks and firms respectively. The entry condition for banks or financiers BB must have a positive slope because a higher number of firms relative to banks increases the profit opportunities for banks. In order for the zero profit condition to be fulfilled, this must be balanced by a higher vacancy rate relative to the unemployment rate which reduces profit opportunities for firms and via the profit sharing contract also for banks. In contrast, the entry condition for firms must have a negative slope because a tighter labor market, that is, a greater vacancy rate relative to the unemployment rate, reduces profit opportunities for firms and must thus be counterbalanced by a more liquid financial market, that is, a smaller number of firms relative to banks in order for the zero profit condition to hold. Total equilibrium is given by the intersection of both curves at the point $\mathrm{E}$ with equilibrium financial market tightness being $\phi^{*}$ and equilibrium labor market tightness being $\theta^{*}$.

9 For the formal solution, see Wasmer and Weil (2000). 
Figure 1: Total Equilibrium

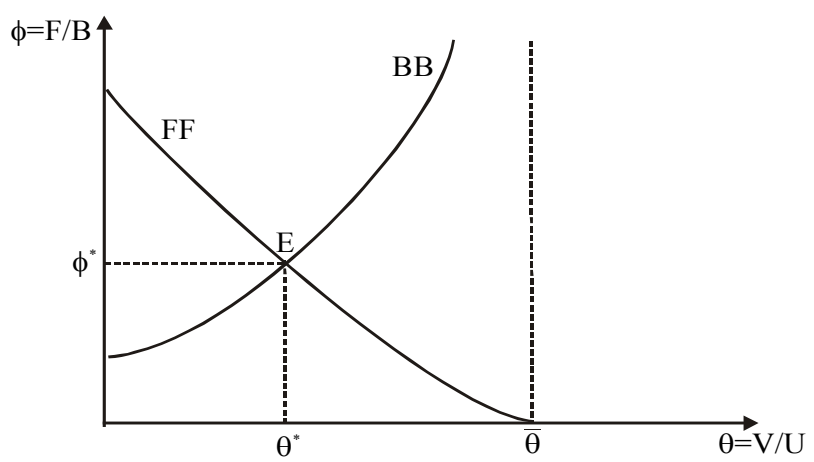

Source: Wasmer and Weil $(2000,16)$.

Higher search costs for banks would shift the BB curve to the north-west without affecting the FF curve thus worsening labor market performance and reducing the liquidity on the financial market. Lower search costs for firms for finding a suitable bank would turn the FF curve clockwise around the given intersection point with the $\mathrm{x}$-axis thus improving labor market performance and reducing the liquidity on the financial market. Higher profits of firms, due for example to structural reforms of the labor market, would shift both curves to the east thus greatly improving labor market performance, but leaving the liquidity of the financial market in the end unchanged.

The financial market would work perfectly well if neither banks nor firms had to incur search costs on the financial market, that is, for $k=0$ and $c=0$. The transition probability for firms in the recruitment phase $p(\phi)$ would then be equal to one. There would be no financial market restriction in this case and the equilibrium tightness of the financial market would then be $\phi^{*}=0$. This corresponds with an equilibrium labor market tightness $\bar{\theta}$ which is unequivocally greater than with the financial market restriction: $\theta^{*}<\bar{\theta}$. Hence, the equilibrium vacancy rate relative to the unemployment rate is reduced by adding financial market frictions to labor market imperfections. Theory therefore predicts unequivocally that a malfunctioning financial or venture capital market with greater matching frictions reduces the quasi-equilibrium employment rate and output, whereas it raises the quasi-equilibrium unemployment rate. Thus, there should be a positive relationship between labor market performance and the development of the venture capital market, as measured by venture capital investments relative to GDP for example. 


\section{Empirical Estimation}

\subsection{Model and Estimation Procedure}

In this section we estimate the impact of variables measuring venture capital investment on employment growth based on the assumption that a well-functioning venture capital market is mainly conducive to job creation in new and innovative firms and in integrating young people quickly into the regular labor market. It might thus accelerate the process of structural change because venture capital investment is unlikely to be of much help in preserving jobs in old and declining industries which are at risk of disappearing. Hence, venture capital investment can be expected to have a more significant effect on employment growth than on official unemployment rates. The model is estimated using panel data on a sample of 20 OECD countries over the period $1986-1999 .{ }^{10}$ The data and its sources described in Table 1.

\section{Table 1: Description of the Labor Market and Capital Market Variables} (about here)

We begin our analysis with the following equation:

$\ln E M P_{i t}=\alpha V C_{i t}+\beta \ln G D P_{i t}+\delta_{j} X_{j i t}+\varepsilon_{i t}$,

where $E M P$ is an index of employment for country $i$ in period $t, V C_{i t}$ is our measure of venture capital for country $i$ in period $t, G D P$ is the level of real gross domestic product for country $i$ in period $t$, included as a cyclical control variable following Wasmer and Weil (2000) and $X_{j i t}$ is a vector of $j$ additional variables used to control for key institutional variables. The above model is a standard static panel model. In the case of labor market variables as in many other economic situations, there are reasons to believe that such a model may be dynamically misspecified. As such, we specify a second estimating equation:

$\ln E M P_{i t}=\gamma \ln E M P_{t-1}+\alpha V C_{i t}+\beta \ln G D P_{i t}+\delta_{j} X_{j i t}+\varepsilon_{i t}$,

where $E M P_{t-1}$ are lags of the dependent variable. This has the appeal that it models employment in a dynamic context, which allows venture capital to have both a short-run and a long-run impact. Dynamic panel models such as that in equation 5 are characterized by the presence of a lagged dependent variable, which creates a number of econometric issues. The major problem that arises when introducing a lagged dependent variable as an explanatory variable is that the error term and the lagged dependent variable are correlated, with the lagged dependent variable being correlated with the individual specific effects that are subsumed into the

10 The 20 countries being: Austria, Belgium, Denmark, Finland, France, Germany, Ireland, Italy, Netherlands, Norway, Portugal, Spain, Sweden, Switzerland, United Kingdom, Canada, United States of America, Japan, Australia and New Zealand. 
error term. This implies that standard estimators are biased, and as such an alternative method of estimating such models is required.

A now standard procedure to provide consistent estimates is to adopt an instrumental variable procedure, which instruments the lagged dependent variable. Although a number of candidates are possible, the Arellano and Bond (1991) approach is adopted as this will generate the most efficient estimates. The validity of this approach requires a lack of second order serial correlation in the dynamic specification, so tests for this are presented with the results. Overall instrument validity is also examined using a Sargan test ${ }^{11}$ of over identifying restrictions. The null hypothesis of the Sargan test is of the exogeneity of the instrument set.

We consider a similar specification for both the static and dynamic model. Given the above discussion therefore, the final estimating equations we employ are:

$D \ln E M P_{i t}=\alpha D V C_{i t}+\beta D G D P_{i t}+\delta_{j} X_{j i t}+D \varepsilon_{i t}$,

and

$D \ln E M P_{i t}=\gamma D \ln E M P_{t-1}+\alpha D V C_{i t}+\beta D \ln G D P_{i t}+\delta_{j} X_{j i t}+D \varepsilon_{i t}$,

where $D$ refers to the first difference of the variable in question. By taking first differences from most of our variables, we consider a consistent specification in both the dynamic and static models. We estimate therefore the impact on the (approximate) growth of employment of the change in venture capital ${ }^{12}$, the change in GDP and of additional labor market institution variables. One thing to note from these equations however is that the additional variables accounting for institutional variables are included in levels rather than differences, these are included in levels since they show little variation across time.

We sequentially use two measures of venture capital, these being either the change in venture capital $(D V C)$ or the change in early stage venture capital (DINVEARLY). DVC is defined as the seed, start-up and expansion (both government and private sector funded) as per million of average GDP, while DINVEARLY is used to account for early stage venture capital only, and is defined as the seed and start-up (both government and private sector funded) as per million of average GDP. There is good reason to believe that these variables measuring venture capital may be endogenous. This is not only valid with respect to the labor market variables but also to another independent variable, namely real

11 Following Sargan (1958).

12 We also included in various specifications the change in the log of venture capital. This resulted in positive coefficients, but the results were not as strong, in that the coefficients were not always significant. Similarly, we also included in various specifications GDP growth (i.e. the change in the log of GDP) as opposed to simply the change in GDP. This didn't affect the results a great deal, though in a small number of cases GDP growth was not significant where the change in GDP was. These results are available on request. 
GDP that is used as a cyclical control variable in our context. Hence, in the case of a significant coefficient of venture capital, one could argue that the demand for finance has been strong and the supply of venture capital supply has been stimulated in those countries that have been innovative and able to create jobs (strong employment growth) and where the macroeconomic climate has been favorable and macroeconomic policy has been supportive ${ }^{13}$. In this case, both employment and venture capital investment may then be driven by a third factor. Estimated coefficients of venture capital might then be biased, although we will point out later on in section 3.2 that the correlation coefficient between the change in VC investment and the change in real GDP is surprisingly low. Hence, to account for the problem of endogeneity of the venture capital variable and thus for possible reverse causality we instrument the venture capital variables, employing the second lag of the venture capital variables as instruments.

The additional variables in the model are included to control for key institutional characteristics. Firstly, we include variables to control for various institutional labor market variables. As such, we include a measure of the benefit replacement ratio (RR1), a measure of the duration of unemployment benefits (Benefit), a measure of employment protection (Empro), the tax wedge (Wedge), the union coverage index (Union) and a measure of the centralization of wage bargaining (Uncord). These it is expected will adequately control for factors that contribute towards labor market rigidities, which include high firing costs, strong unions and generous employment benefits. Secondly, we include a variable to account for the presence of institutional capital markets, by including an index of the legal system's protection of creditors in case of a firm's liquidation or re-organization (CreditRight). This variable reflects the legal position of creditors vis-à-vis firms in case of financial distress.

With respect to the sign on the coefficients of these additional variables included in our regressions, we expect the following marginal coefficients for the employment equations. ${ }^{14}$ We expect RR1, Benefit, Empro, Wedge and Union to be negative, while the coefficients on Uncord and CreditRight are expected to exert a positive impact on employment growth. At the same time we expect that the coefficients on the changes in the two venture capital variables $(D V C$ and DINVEARLY) would be positive so that more venture capital investment would raise employment growth.

\subsection{Results}

We begin our formal empirical analysis with tests of the non-stationarity of the variables under consideration. The test we applied was the widely used panel data

13 Given that labor market institutions are often badly measured, an alternative view would be that venture capital may capture their effects.

14 See for example, Blanchard and Wolfers (1999), and Layard and Nickell (1997). 
unit root test by Levin and Lin (2002). ${ }^{15}$ This test represents a direct extension of the univariate ADF test setting to panel data. As usual, we difference the variables until they are stationary. Hence, we will follow a consistent approach in our estimations and only use a set of stationary variables. Overall, the test results for the levels reveal that the null-hypothesis of non-stationarity has to be accepted for most of the variables under consideration. The evidence is borderline in only a few specifications of the test equations. However, the ADF-tests for the first differenced variables deliver overwhelming evidence of stationarity.

Based on our theoretical arguments, we conjecture that controlling for the key institutional variables on the labor and the capital market, the presence of venture capital improves labor-market performance in a cross-country panel analysis. To test for a significant relationship between venture capital and labor-market performance, we undertake estimations in differences and for early stage as well as for total venture capital investment. The models were estimated using the package Dynamic Panel Data 98 for GAUSS, details of which are provided by Arellano and Bond (1998). The following tables display the results from estimating equations 6 and 7. The tables report the coefficients along with heteroscedastic consistent t-ratios. The validity of the dynamic models depends upon a lack of second order serial correlation and the validity of the instrument set, tested for with the Sargan test. Results of these tests are reported in the tables.

Table 2: Total Venture Capital Investment and Employment Growth (about here)

Table 3: Early Stage Venture Capital Investment and Employment Growth (about here)

To start with, note that the Sargan test for the validity of the instruments tends to be insignificant and that the test of second order serial correlation is insignificant in the dynamic model, suggesting that the models are well specified. If we begin by examining the coefficients on the additional variables included in the model, we see that the coefficient on the change in GDP is positive as expected, and tends to be significant in both tables and in both the static and dynamic specification. Hence, the well-known prior that GDP growth is one important determinant of employment growth is corroborated by our estimations. ${ }^{16}$

We now concentrate on the variables representing venture capital. Table 2 examines the impact of the change in venture capital on the growth of employment. The coefficients on DVC are always positive as expected, and they are also significant at least at the 10 percent level in five out of the six cases

15 Belke, Fehn and Foster (2003) display the results of applying this unit root test to our set of variables.

16 Belke, Fehn and Foster (2003), pp. 24f., discuss why the coefficients on the institutional variables included in the models tend to be very small. 
depicted. The dynamic results tend to be more supportive of a significant impact of $D V C$ on the growth of employment, in the sense that the coefficients tend to be significant at higher levels of significance. At the same time, the coefficients in the static model tend to be larger in absolute value.

Table 3 replaces $D V C$ with DINVEARLY, in order to examine the impact of early stage venture capital investment on employment growth. The coefficients on DINVEARLY are not quite as supportive of an impact of early stage venture capital investment on employment growth possibly reflecting the fact that expansion investment which is not included here affects job creation most directly. Although the coefficient is positive as expected in five out of six cases, it is now significant in only half of the cases. Once again, the results are more supportive in the dynamic case, with more significant coefficients being found, which indicates once again that the employment effects of venture capital investment are part of a dynamic process.

A potential caveat raised in section 3.1 was that the estimated coefficients of venture capital might be biased due to a reverse causality between real GDP growth and the change in $\mathrm{VC}$ investment. A short inspection of the correlation coefficients between the change in both definitions of $\mathrm{VC}$ investments and real GDP growth listed in Belke, Fehn and Foster (2003), Table 5, reveals that the empirical realizations of the former are in fact surprisingly low. Hence, although we accounted for the theoretical problem of endogeneity of the venture capital variable and thus for possible reverse causality a priori by instrumenting the venture capital variables, this problem does actually not seem to be a problem in our sample. ${ }^{17}$

\section{Conclusions}

Many economists argue that labor market rigidities and generous welfare states are at the core of persistently low job creation in continental Europe compared to most Anglo-Saxon countries and especially compared to the US in the nineties. However, it is important to note that job creation might in addition depend on markets which are complementary to the labor market and whose malfunctioning might also constitute a bottleneck for job creation. Such a bottleneck might be the possibility for young and innovative firms to obtain finance for their highly risky projects. Hence, by leaving out capital market variables, past empirical results might have overstated the impact and significance of some of the labor market variables. The ability of a country to encourage and sustain technological innovation by entrepreneurial firms is after all one of the main sources of economic and employment growth.

17 Based on our dynamic results, it is possible to estimate the long-run contribution of venture capital on employment growth. The long-run effect of venture capital for the results displayed in Tables 2-3 is reported in Belke, Fehn and Foster (2003), pp. 27ff. They identify an interval of a 1.0 to a 1.8 percent employment growth effect of venture capital. 
Economic intuition suggests that venture capitalists have to play a key role in this respect because they have often been able to provide promising companies with adequate risk financing, this especially being the case in the US. Economists have so far paid relatively little attention to the possibility of a virtuous circle between entrepreneurial dynamism, innovative start ups, a dynamic venture capital industry and job creation. It has recently been argued that it is a challenging empirical problem to demonstrate a causal relationship between the presence of venture capital investment and innovation or job growth. ${ }^{18}$ This paper delivers pioneering empirical evidence of such a link at the macroeconomic level. We are able to show that venture capital is able to significantly raise employment growth and job creation. We conjecture that venture capital is mainly conducive to job creation in new and innovative firms and that it facilitates the process of structural change toward the new economy.

These results should not be misinterpreted as a justification for government subsidies to the venture capital industry or for government-run venture capital activities. Rather, the government should provide an institutional framework which is favorable to the development of a flourishing private venture capital industry and entrepreneurial dynamism. There exist a number of possible ways of doing so. First, the pension system could be capitalized to a greater extent and pension funds could be allowed to invest part of their assets in venture capital firms. Based on the US example, this should further spur the development of the venture capital market in continental Europe. ${ }^{19}$ Second, a well-functioning market for initial public offerings such as NSDAQ needs to be created as an exit route for venture capitalists. This is especially important since European attempts at doing so such as the "Neuer Markt" have recently crashed spectacularly. Trust and transparency are clearly key issues in recreating such an exit market so that there is especially a need for strong and unequivocal corporate governance and accounting rules.

\section{References}

Acemoglu, D., P. Aghion and F. Zilibotti (2002). Distance to Frontier, Selection, and Economic Growth, NBER Working Paper 9066, NBER, Cambridge, MA.

Arellano, M. and S. Bond (1991). Some Tests of Specification for Panel Data: Monte Carlo Evidence and an Application to Employment Equations, Review of Economic Studies, 58: 277-297.

Arellano, M. and S. Bond (1998). Dynamic Panel Data Estimation Using DPD98 for GAUSS: A Guide for Users, Working Paper of the Institute for Fiscal Studies No. 88/15, London.

Asian Venture Capital Journal (2000). The Guide to Venture Capital in Asia - The Asian Venture Capital and Private Equity Source Book. $11^{\text {th }} \mathrm{ed}$.

18 See Gompers and Lerner (2001).

19 See Jeng and Wells (2000). 
Baygan, G. and M. Freudenberg (2000). Venture Capital: Supply vs. Demand Issues. Directorate for Science, Technology and Industry, Industry Committee, OECD, Paris.

Belke, A, R. Fehn and N. Foster (2003), Does Venture Capital Spur Employment Growth?, CESifo Working Paper 930, München.

Berthold, N. and R. Fehn (2002). Unemployment in Germany: Reasons and Remedies. Paper presented at the CESifo Conference on Unemployment in Europe, December 6-7, Munich.

Blanchard, O. and J. Wolfers (1999). The Role of Shocks and Institutions in the Rise of European Unemployment: The Aggregate Evidence, NBER Working Paper 7282, NBER, Cambridge, MA.

Bottazzi, L. and M. Da Rin (2001). Venture Capital in Europe: Euro.NM and the Financing of European Innovative Firms. Paper Presented at the $33^{\text {rd }}$ Economic Policy Meeting, Stockholm, April 6-7, 2001.

Bottazzi, L. and M. Da Rin (2002). Financing Entrepreneurial Firms in Europe: Facts, Issues and Research Agenda. Paper Presented at the CESifo Conference on Venture Capital, Entrepreneurship, and Public Policy, Munich, November 22-23, 2002.

European Venture Capital Association (2000). European Venture Capital Yearbook Pan-European Private Equity and Venture Capital Statistics.

Fehn, R. (2002). Schöpferische Zerstörung und struktureller Wandel - Wie beeinflussen Kapitalbildung und Kapitalmarktunvollkommenheiten die Beschäftigungsentwicklung?. Baden-Baden.

Gompers, P. and J. Lerner (2001). The Venture Capital Revolution, Journal of Economic Perspectives. 15: 145-168.

Heckman, J. (2002). Flexibility and Job Creation: Lessons for Germany, NBER Working Paper 9194, NBER, Cambridge, MA.

Hellmann, T. and M. Puri (2000). The Interaction Between Product Market and Financing Strategy: The Role of Venture Capital, Review of Financial Studies. 13: 959-984.

Hubbard, G. (1998). Capital-Market Imperfections and Investment, Journal of Economic Literature. 36: 193-225.

Jeng, L.A. and P.C. Wells (2000). The Determinants of Venture Capital Funding: Evidence across Countries, Journal of Corporate Finance. 6: 241-289.

Kortum, S. and J. Lerner (1998). Does Venture Capital Spur Innovation?, NBER Working Paper 6846, NBER, Cambridge, MA.

La Porta, R., F. Lopez-de-Silanez and A. Shleifer (1998). Law and Finance, Journal of Political Economy. 106: 1113-1155.

Layard, R. and S. Nickell (1997). Labour Market Institutions and Economic Performance, Centre for Economic Performance Discussion Paper Series, No. 23, London School of Economics, London.

Levin, A. and C. F. Lin (2002). Unit Root Tests in Panel Data: Asymptotic and Finite-sample Properties, Journal of Econometrics. 108: 1-24.

National Venture Capital Association (2000). National Venture Capital Yearbook. 
Nickell, S. (1997). Unemployment and Labour Market Rigidities: Europe versus North America, Journal of Economic Perspectives. 11: 55-74.

Sargan, J.D. (1958). The Estimation of Economic Relationships Using Instrumental Variables, Econometrica. 48: 879-897.

Siebert, H. (1997). Labor Market Rigidities - At the Root of Unemployment in Europe, Journal of Economic Perspectives. 11: 37-54.

Wasmer, E. and P. Weil (2000). The Macroeconomics of Labor and Credit Market Imperfections, IZA Discussion Paper 179, Bonn. 
Table 1: Description of the Labor Market and Capital Market Variables

\begin{tabular}{|c|c|}
\hline \multicolumn{2}{|l|}{ Macroeconomic time series } \\
\hline $\begin{array}{l}\text { Total employment } \\
\text { (EMP) }\end{array}$ & $\begin{array}{l}\text { Civilian or (if not available) total economy employment (employees and self employed). Source: } \\
\text { OECD Main Economic Indicators. }\end{array}$ \\
\hline $\begin{array}{l}\text { Real gross domestic product } \\
\text { (GDP) }\end{array}$ & Source: OECD Main Economic Indicators \\
\hline \multicolumn{2}{|c|}{ Institutional labor market variables } \\
\hline $\begin{array}{l}\text { Benefit replacement ratio } \\
\text { (RR1) }\end{array}$ & $\begin{array}{l}\text { Average replacement rate over the first year of an unemployment spell. Source: Blanchard and } \\
\text { Wolfers (1999), pp. } 11 \text { ff... Three realizations per country (for 1986-89, 1990-94 and 1995-99). } \\
\text { Indicator displays more variability than RRATE. }\end{array}$ \\
\hline $\begin{array}{l}\text { Benefit duration } \\
\text { (BENEFIT) }\end{array}$ & $\begin{array}{l}\text { Duration of unemployment benefits (years, } 4 \text { years meaning indefinite). Source: Layard and } \\
\text { Nickell (1997), pp. } 11 \text { ff., and complementary data delivered by S. Nickell. }\end{array}$ \\
\hline $\begin{array}{l}\text { Union coordination index } \\
\text { (UNCORD) }\end{array}$ & $\begin{array}{l}\text { Union co-ordination in wage bargaining. Index with } 3=\text { high, } 2=\text { middle, } 1=\text { low. Source: Layard } \\
\text { and Nickell (1997), Table } 2 \text {, and complementary data delivered by S. Nickell. }\end{array}$ \\
\hline $\begin{array}{l}\text { Union coverage index } \\
\text { (UNION) }\end{array}$ & $\begin{array}{l}\text { Index, } 3=\text { over } 70 \% \text { covered, } 2=25-70 \% \text { covered, } 3=\text { under } 25 \% \text { covered. Source: Layard and } \\
\text { Nickell (1997), Table } 2 \text {, and complementary data delivered by S. Nickell. }\end{array}$ \\
\hline $\begin{array}{l}\text { Employment protection index } \\
\text { (EMPRO) }\end{array}$ & $\begin{array}{l}\text { Country ranking with } 20 \text { as the most strictly regulated. Source: Layard and Nickell (1997), p. } 6 \text {, } \\
\text { Table 2, and complementary data delivered by S. Nickell. }\end{array}$ \\
\hline $\begin{array}{l}\text { Tax wedge } \\
\text { (WEDGE)) }\end{array}$ & $\begin{array}{l}\text { Total tax wedge (in \%). Sum of the payroll tax rate, the income tax rate and the consumption tax } \\
\text { rate. Average rates derived from national income and tax data. Source: Layard and Nickell (1997), } \\
\text { p.4, Table 1, and complementary data delivered by S. Nickell. }\end{array}$ \\
\hline \multicolumn{2}{|c|}{ Venture capital investment time series } \\
\hline $\begin{array}{l}\text { Venture capital investment } \\
\text { (VC) }\end{array}$ & $\begin{array}{l}\text { Seed, startup and expansion (both government and private sector funded) as per mil of average } \\
\text { GDP. Source: Own calculations based on Asian Venture Capital Journal (2000), Baygan and } \\
\text { Freudenberg (2000), European Venture Capital Association (2000), National Venture Capital } \\
\text { Association (2000), Jeng, and Wells (2000) }\end{array}$ \\
\hline $\begin{array}{l}\text { Early stage venture capital } \\
\text { investment } \\
\text { (INVEARLY) }\end{array}$ & $\begin{array}{l}\text { Seed and startup (both government and private sector funded) as per mil of average GDP. Source: } \\
\text { Own calculations based on Asian Venture Capital Journal (2000), Baygan and Freudenberg } \\
\text { (2000), European Venture Capital Association (2000), National Venture Capital Association } \\
\text { (2000), Jeng and Wells (2000) }\end{array}$ \\
\hline \multicolumn{2}{|c|}{ Institutional capital market variables } \\
\hline $\begin{array}{l}\text { Creditor rights } \\
\text { (CREDITRIGHT) }\end{array}$ & $\begin{array}{l}\text { Index of the legal system's protection of creditors in case of a firm's liqidation or reorganization. } \\
\text { Range: } 0 \text { to } 4,4 \text { is the highest level of creditor protection. Source: La Porta et al. (1998), p. 1136, } \\
\text { Table } 3 \text {. }\end{array}$ \\
\hline
\end{tabular}


Table 2: Total Venture Capital Investment and Employment Growth

\begin{tabular}{|c|c|c|c|c|c|c|}
\hline DlnEMP & 1 & 2 & 3 & 4 & 5 & 6 \\
\hline DlnEMP-1 & & & & $\begin{array}{l}0.51 \\
(9.08)^{* * *}\end{array}$ & $\begin{array}{l}0.41 \\
(5.81)^{* * *}\end{array}$ & $\begin{array}{l}0.43 \\
(6.02)^{* * *}\end{array}$ \\
\hline DVC & $\begin{array}{l}0.03 \\
(1.95)^{* *}\end{array}$ & $\begin{array}{l}0.03 \\
(1.75)^{*}\end{array}$ & $\begin{array}{l}0.03 \\
(0.94)\end{array}$ & $\begin{array}{l}0.009 \\
(3.37)^{* * *}\end{array}$ & $\begin{array}{l}0.008 \\
(2.6)^{* * *}\end{array}$ & $\begin{array}{l}0.006 \\
(1.87)^{*}\end{array}$ \\
\hline DGDP & & $\begin{array}{l}0.005 \\
(1.41)^{* *}\end{array}$ & $\begin{array}{l}0.005 \\
(1.64)^{*}\end{array}$ & & $\begin{array}{l}0.005 \\
(6.39) * * *\end{array}$ & $\begin{array}{l}0.006 \\
(5.1)^{* * *}\end{array}$ \\
\hline RR1 & & & $\begin{array}{l}-0.0009 \\
(-0.7)\end{array}$ & & & $\begin{array}{l}0.0001 \\
(0.51)\end{array}$ \\
\hline Benefit & & & $\begin{array}{l}0.003 \\
(0.32)\end{array}$ & & & $\begin{array}{l}-0.0002 \\
(-0.11)\end{array}$ \\
\hline Uncord & & & $\begin{array}{l}0.03 \\
(1.14)\end{array}$ & & & $\begin{array}{l}0.005 \\
(0.79)\end{array}$ \\
\hline Empro & & & $\begin{array}{l}0.002 \\
(0.46)\end{array}$ & & & $\begin{array}{l}0.001 \\
(2.03)^{* *}\end{array}$ \\
\hline Wedge & & & $\begin{array}{l}-0.0001 \\
(-0.11)\end{array}$ & & & $\begin{array}{l}-0.0001 \\
(-0.23)\end{array}$ \\
\hline Credit Right & & & $\begin{array}{l}-0.01 \\
(-0.67)\end{array}$ & & & $\begin{array}{l}0.003 \\
(1.11)\end{array}$ \\
\hline Union & & & $\begin{array}{l}-0.03 \\
(-0.61)\end{array}$ & & & $\begin{array}{l}-0.02 \\
(-1.53)\end{array}$ \\
\hline Constant & $\begin{array}{l}0.005 \\
(1.44)\end{array}$ & $\begin{array}{l}-0.006 \\
(-0.83)\end{array}$ & $\begin{array}{l}0.07 \\
(0.71)\end{array}$ & $\begin{array}{l}0.003 \\
(2.98)^{* * *}\end{array}$ & $\begin{array}{l}-0.007 \\
(-4.26)^{* * *}\end{array}$ & $\begin{array}{l}0.002 \\
(0.13)\end{array}$ \\
\hline Wald Test & $3.79 *$ & $8.24 * *$ & 14.24 & $139.8^{* * *}$ & $118.2 * * *$ & $298.3^{* * *}$ \\
\hline Sargan Test & $\begin{array}{l}0.45 \\
(\mathrm{df}=10) \\
(\mathrm{p}=0.45)\end{array}$ & $\begin{array}{l}6.92 \\
(d f=9) \\
(p=0.65)\end{array}$ & $\begin{array}{l}0.94(\mathrm{df}=2) \\
(\mathrm{p}=0.63)\end{array}$ & $\begin{array}{l}96.5^{* *} \\
(\mathrm{df}=75) \\
(\mathrm{p}=0.048)\end{array}$ & $\begin{array}{l}79.62(\mathrm{df}=74) \\
(\mathrm{p}=0.31)\end{array}$ & $\begin{array}{l}56.8(\mathrm{df}=67) \\
(\mathrm{p}=0.81)\end{array}$ \\
\hline $\begin{array}{l}1^{\text {st }} \text { Order } \\
\text { Correlation }\end{array}$ & $2.46^{* *}$ & $2.04 * *$ & 1.4 & 0.66 & -1.05 & 0.11 \\
\hline $\begin{array}{l}2^{\text {nd }} \text { Order } \\
\text { Correlation }\end{array}$ & $2.09 * *$ & 1.61 & 1.13 & -0.3 & -0.38 & 1.05 \\
\hline
\end{tabular}


Table 3: Early Stage Venture Capital Investment and Employment Growth

\begin{tabular}{|c|c|c|c|c|c|c|}
\hline DlnEMP & 1 & 2 & 3 & 4 & 5 & 6 \\
\hline DlnEMP-1 & & & & $\begin{array}{l}0.51 \\
(11.04) * * *\end{array}$ & $\begin{array}{l}0.41 \\
(5.16) * * *\end{array}$ & $\begin{array}{l}0.41 \\
(4.73) * * *\end{array}$ \\
\hline DIN & 0.01 & 0.04 & -0.02 & 0.02 & 0.02 & 0.01 \\
\hline VEARLY & $(0.59)$ & $(1.91 *)$ & $(-0.27)$ & $(2.44)^{* *}$ & $(1.92)^{*}$ & $(1.51)$ \\
\hline DGDP & & $\begin{array}{l}0.007 \\
(3.44)^{* * *}\end{array}$ & $\begin{array}{l}0.01 \\
(1.46)\end{array}$ & & $\begin{array}{l}0.005 \\
(7.69)^{* * *}\end{array}$ & $\begin{array}{l}0.006 \\
(5.87)^{* * *}\end{array}$ \\
\hline RR1 & & & $\begin{array}{l}-0.0008 \\
(-0.48)\end{array}$ & & & $\begin{array}{l}0.00004 \\
(0.2)\end{array}$ \\
\hline Benefit & & & $\begin{array}{l}0.007 \\
(0.54)\end{array}$ & & & $\begin{array}{l}0.0002 \\
(0.1)\end{array}$ \\
\hline Uncord & & & $\begin{array}{l}-0.01 \\
(-0.63)\end{array}$ & & & $\begin{array}{l}0.006 \\
(0.83)\end{array}$ \\
\hline Empro & & & $\begin{array}{l}-0.001 \\
(-0.36)\end{array}$ & & & $\begin{array}{l}0.001 \\
(1.82)^{*}\end{array}$ \\
\hline Wedge & & & $\begin{array}{l}0.002 \\
(0.78)\end{array}$ & & & $\begin{array}{l}-0.00003 \\
(-0.12)\end{array}$ \\
\hline Credit Right & & & $\begin{array}{l}-0.00002 \\
(-0.0008)\end{array}$ & & & $\begin{array}{l}0.005 \\
(1.05)\end{array}$ \\
\hline Union & & & $\begin{array}{l}-0.01 \\
(-0.21)\end{array}$ & & & $\begin{array}{l}-0.02 \\
(-1.67)^{*}\end{array}$ \\
\hline Constant & $\begin{array}{l}0.008 \\
(3.28)^{* * *}\end{array}$ & $\begin{array}{l}-0.01 \\
(-1.9)^{*}\end{array}$ & $\begin{array}{l}-0.03 \\
(-0.21)\end{array}$ & $\begin{array}{l}0.003 \\
(3.02)^{* * *}\end{array}$ & $\begin{array}{l}-0.007 \\
(-3.67)^{* * *}\end{array}$ & $\begin{array}{l}0.004 \\
(0.18)\end{array}$ \\
\hline Wald Test & 0.35 & $11.91 * * *$ & $33.74 * * *$ & $232.08 * * *$ & $87.4^{* * *}$ & $264.47 * * *$ \\
\hline Sargan Test & $\begin{array}{l}16.21 * \\
(d f=10) \\
(p=0.09)\end{array}$ & $\begin{array}{l}13.26(\mathrm{df}=9) \\
(\mathrm{p}=0.15)\end{array}$ & $\begin{array}{l}1.1 \\
(\mathrm{df}=2) \\
1.2 \\
(\mathrm{p}=0.58)\end{array}$ & $\begin{array}{l}100.08 * * \\
(\mathrm{df}=75) \\
(\mathrm{p}=0.03)\end{array}$ & $\begin{array}{l}84.68(\mathrm{df}=74) \\
(\mathrm{p}=0.19)\end{array}$ & $\begin{array}{l}51.83(\mathrm{df}=67) \\
(\mathrm{p}=0.91)\end{array}$ \\
\hline $\begin{array}{l}1^{\text {st }} \text { Order } \\
\text { Correlation }\end{array}$ & $2.61 * * *$ & $1.78^{*}$ & 1.35 & 0.68 & -0.97 & 0.94 \\
\hline $\begin{array}{l}2^{\text {nd }} \text { Order } \\
\text { Correlation }\end{array}$ & $2.15^{* *}$ & 0.66 & 1.21 & -1.06 & -0.65 & 1.25 \\
\hline
\end{tabular}

